\title{
Environmental management methods to control the vector of communicable diseases with emphasis on drainage: A review article.
}

\author{
Dehghani $\mathbf{R}^{1}$, Kassiri $\mathbf{H}^{2 *}$, Rabbani $\mathrm{D}^{1}$, Mazaheri Tehrani $\mathrm{A}^{\mathbf{3}}$, Gharagazloo $\mathrm{F}^{1}$ \\ ${ }^{1}$ Social Determinants of Health (SDH) Research Center, Department of Environmental Health Engineering, Kashan \\ University of Medical Sciences, Kashan, Iran \\ ${ }^{2}$ Department of Medical Entomology, School of Health, Ahvaz Jundishapur University of Medical Sciences, Ahvaz, \\ Iran
}

${ }^{3}$ Department of Environmental Health Engineering, School of Health, Hamadan University of Medical Sciences, Hamadan, Iran

\begin{abstract}
Health contaminants endanger human health by transmitting diseases. Due to the importance of combating pests and the risk of environmental pollution because of exertion of pesticide chemistry, the use of healthy control methods become important. Therefore, the use of environmental pest control procedures is essential. The purpose of this review study is to identify environmental pest management methods. The study was conducted through a review method. By using keywords in databases, the Internet and related sites and valid journals, articles and research were searched and ultimately qualified sources were selected and introduced, criticized and applied. Health pest habitats are different, so similar actions should be taken on any group that has a common habitat. Conducting environmental measures should slow down the transmission of disease. Environmental methods have been used for a long time for its simple and unpolluted use and lasting effects. Recognizing the biological cycle of each health pest with regard to the type of climate and habitat is a prerequisite for the effective use of environmental control methods for pest control. By using environmental pest management methods, instead of chemical methods, the environment can be kept clean and healthy to provide health and hygiene of the human community, which is one of the main goals of health organizations and authorities.
\end{abstract}

Keywords: Health pests, Drainage, Environmental control, Communicable diseases.

Accepted on February 4, 2019

\section{Introduction}

Since a long time ago, some arthropods have been considered as causing disturbance and fear for humans and other living organisms $[1,2]$. Transmission of various pathogens by insects and arthropods and the creation of large epidemics have endangered the lives of thousands of people and resulted in many deaths $[3,4]$. These groups of arthropods that hurt and endanger human health are called health pests [4]. Some arthropods develop disease directly in humans or animals; the disease of the scabies is infected by the contact with an infected person or contaminated equipment such as clothes and bed. The cause of this disease is fed from human skin. It penetrates and lay inside it $[5,6]$. Bed bugs further cause harassment of humans [7]. Larvae of some flies make the human and livestock ill by the activity and eating flesh of livestock or human. These insects cause contamination of human or animal living tissues and cause Myiasis disease. Myiasis indicators can attack and damage any tissue and organs [8-11]. Habitat and breeding places are part of the life of harmful arthropods in aquatic environments, including mosquitoes. They are considered to be the most dangerous health pests and play a key role in the transmission of a large number of pathogens [12-14]. A number of other female biting insects, such as stable flies, are lying in vegetal waste along the water streams or in the bed and under the straw [15]. Cockroaches, by contaminating food through pathogens in the toilet and garbage, are responsible for transmitting bacterial diseases such as diarrhea, dysentery, cholera, typhoid fever, viral diseases such as polio, and allergic reactions such as skin discomfort, itching, flushing of the eyelids and respiratory incontinence, as well as cockroaches, carry eggs of parasite and single cell cysts in the environment [16,17]. Some mice interfere with the spread of transmissible diseases, including domesticated mice living in humans and surrounding areas, and others are wild mice that naturally repository of some human-infected diseases. There are a number of mice that host some of the worms. In the natural state of these diseases and parasitic infections, the rodents are kept in focus between them [18]. 
At present, the most common method for combating pests is the use of chemicals known as pests, which differ in terms of chemical structure, but the commonality of all of them is the contamination of the human environment. Chemical pollution is one of the most important environmental crises. It is estimated that humans in their own environment are inevitably in contact with at least 70,000 types of poison in their environment, and each year their added number is increased. These materials are considered as important pollutants of the human environment [19,20]. Most of these poisons are pesticides. The toxicity of these substances has been reported throughout the world. Except for environmental damage, it has been shown to be resistant to pests and 224,000 people die of unintentional poisoning in developing countries annually [21-24]. Given the increasing role of chemicals in people's daily lives and the high consumption of chemical pesticides in agriculture and sanitation to eliminate various pests, the devastating effects of their use in nature on humans have the potential to cause chronic and dangerous diseases, including cancers $[25,26]$. Scorpions are among the toxic arthropods that cause stings in some tropical regions of Iran and sometimes lead to death [27-31]. The southern and southwest provinces of Iran have the most bites and deaths [32-36].

Due to the variety and frequency of different health pests and the need to combat them and the harmful effects of pesticides, other ways to eliminate pests must be considered, which, as far as possible can be considered as harmful effects of the use of pesticides. Therefore, the increasing needs of the community and the advancement of knowledge and technology in increasing the yield of agricultural products and livestock and reducing the diseases transmitted by pests in livestock and humans requires the use of clean fighting methods [24].

Environmental control methods are the most sustainable pest control methods. These methods cause permanent changes in the environment and create conditions for the development of inappropriate pests. One of these sustainable environmental methods is the implementation and establishment of a drainage system. Drainage is necessary in a situation where the water in the hydrological cycle stays in place, and this sustainability will fuel the transmitter of diseases. In this study, the application of environmental control methods has been investigated with emphasis on drainage systems and its various methods.

\section{Materials and Methods}

The research was conducted through a review method. According to the key words, drainage, health pest control, prevention and environmental control, on the Internet and related sites, and the use of specialized journals in this field, the search for articles and research in this field was done. Key words were searched in the websites related to credible academic journals and scientific databases such as Web of Science, Ovid, PubMed, Systematic Review, SID, Iran Medex, Scirus, Google Scholar, and Medline. The search was more focused on all articles published by 2018 . Then, the articles and resources that provided detailed and technical descriptions of different methods of environmental control and various drainage methods were studied and the rest of others were omitted.

The articles were excluded from the study for linguistic reasons, as well as the type of examination and other aspects of the combat, such as chemical, biological and genetic control, and other fields except the environmental control method. Articles and reference books on available drainage were studied. Finally, while reviewing the sources and expressing various aspects of these surveys, the author's perspective on prevention, control and health pests was presented. The shapes are painted, arranged and rebuilt by the author according to the necessary specifications.

\section{Results and Discussion}

Culicidae family mosquitoes are the most important arthropods of the disease transmission. The mosquitoes of this family transmit some important diseases such as malaria, dengue fever, yellow fever, filariasis, and a number of encephalitis. The mosquitoes of this family are from stagnant or current water at low speeds and any species. Visible water is used as a larval habitat. The environmental pest control methods are one of the most important control methods [12-14].

Drainage is one of the major methods of environmental control. Drainage has various methods that can vary in different conditions, such as soil texture, topography of the land, climate of the area, and drainage type [37-39]. Drainage in the agricultural sector began about 9,000 years ago in Mesopotamia. The first drainage pipes are about 4,000 years old. In Europe, the first underground drainage was installed about 2,000 years ago. The underground drainage was used in Britain around 1810. With the invention of pottery in 1840, the drainage development in Europe accelerated. Drainage in the early 1960s, with the emergence of plastic tubes with a smooth and thin wall, then accelerated with the production of conical tubes. In the 1970s, the use of drainage systems began and accelerated its development [40].

In Iran, the first modern irrigation and drainage networks were constructed in 1931 in the south of the country. The first openair drain was built using a car in 1956 in Shawur District, Khuzestan Province. In 1963, the first underground drainage network was carried out using clay pipes at the Faculty of Agriculture, Jundishapur University in Ahvaz. Then it began in Haft Tappe District, then in the fields of cultivation and industry of Karun and simultaneously, the drainage of the lands of Voshmgir Dam was begun in Gorgan County [41]. The construction of a drainage system is an effective way to control and contest with mosquitoes carrying diseases, because it is cheaper than the use of insecticides, it does not need to be repeated, and in many cases its costs are lower than the annual cost of insecticide delivery. Application of drainage does not have the risk of increasing the resistance of mosquitoes against insecticides, which is clearly established today.

Controlled drainage is a combination of irrigation and drainage. By opening and closing the drain outlet, it is possible 


\section{review article}

to maintain the water level within the soil to an optimum extent. This method has been used for many years in the Netherlands, the United States and Egypt. This method can be used in rice fields and sugar cane in Iran, and in addition to increasing irrigation efficiency, it decreases the number of mosquitoes transmitted the disease [42].

\section{Types of controlled drainage}

Drainage by covered streams: In this method, after digging of drainage canals, using a tree branch, brick, stone and other materials, the water ways is first created in the foothills, and then the soil is poured on them. This method is used in some cases where the required material is high but there is no drainage pipe instead. In this method, the strain slope should be greater than the drainage canals slope using the pipe (Figure 1).

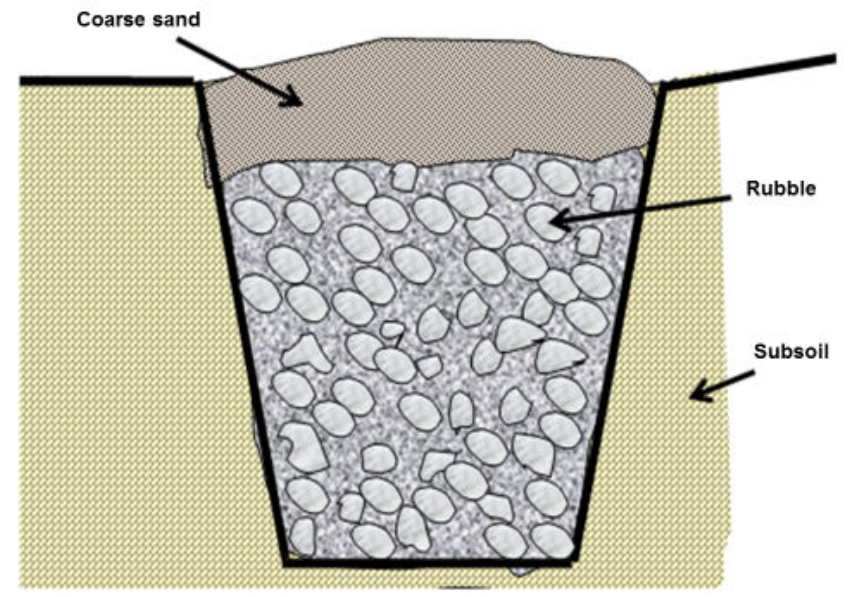

Figure 1. Common French drain filled with rock, rubble or gravel (Prepared by R Dehghani).

Drainage by using Dutch method: In this drainage method, there are no main and subsidiary networks of drainage and the water flows through the wells that come from the impenetrable level to the lower permeable level. The number of these wells varies from 6,000 to 10,000 hectares. Occasionally, in order to use them, they fill the land (Figure 2).

Surface and open drainage: To collect and transfer excess surface water and water needed for irrigation of open drains. In these drains, water flows through the gradient and under the influence of its weight. Outdoor drainage method is performed in areas where there is a problem of surface and underground water. In this method, the land leveling is done arbitrarily and the slope of surface water is extracted from the area.

Water velocities in the small stream are at least 0.45 metres in sandy soils and a maximum of 1.2 metres in clay soils per second. The required slope is at least $0.5 \%$ and maximum $0.6-0.8 \%$ drainage floors should be at least $20 \mathrm{~cm}$ below the groundwater level. The difference in height or shot of each drain should be 15 to $20 \mathrm{~cm}$ from the next drain (Figure 3 ).

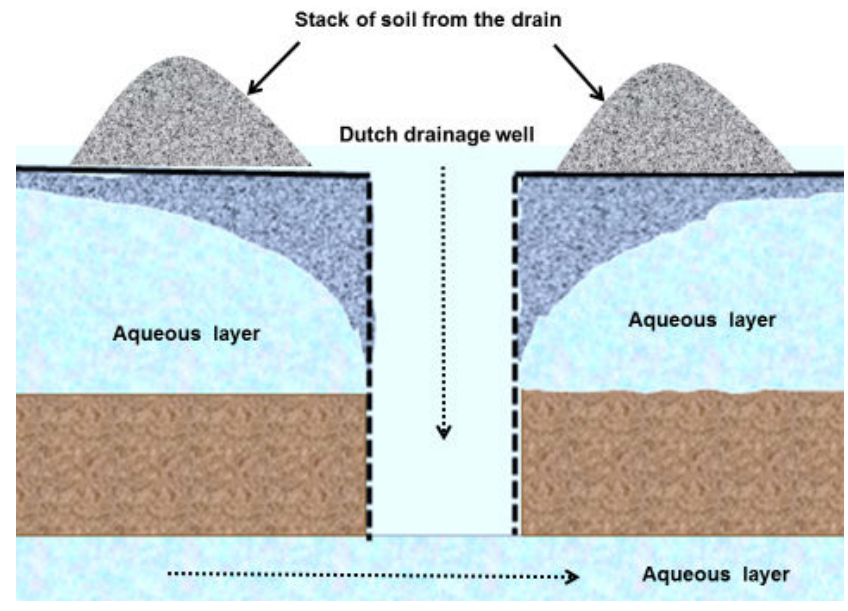

Figure 2. Dutch drainage profile (Prepared by R Dehghani).

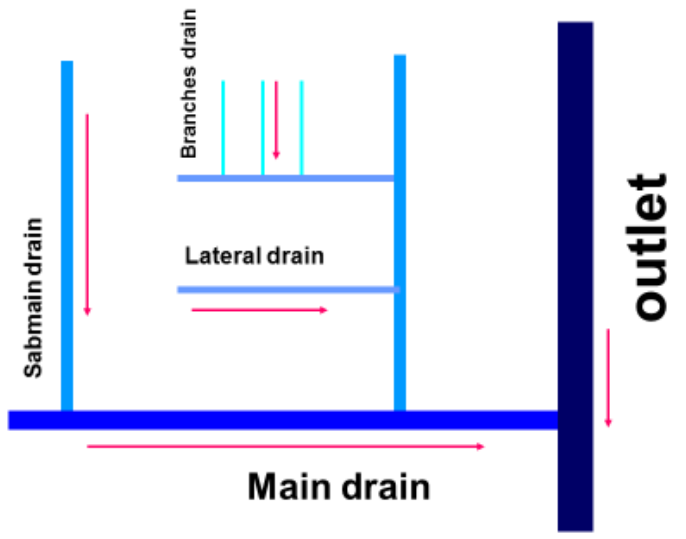

Figure 3. Surface or open drain design (Prepared by R Dehghani).

Inside drainage is used as a pre-fabricated concrete piece due to the lack of soil erosion during filling of drains in downpours. These parts are placed on the drainage floor so that the drain can properly remove the water from the water under normal conditions [42]. When connecting the subsidiary drains, higher drainage should be designed so that it can easily transmit the water of drainage during a load and in any case it does not only cause drain but also operate properly [43]. Open drain is located in the regions of Iran and from the provinces of Khuzestan and Isfahan on the margin of Zayandeh-Rod river.

Mole drain or mosquito nesting: In a mole drain method, a molten cone with a length of 50 to 75 centimeters in clayey soils, at a suitable depth of 10 to $15 \mathrm{~cm}$ in diameter, is created (Figure 4). Usually, the proper depth of the vent is $60 \mathrm{~cm}$ and the channel distance is about 3 metres, so that it can be efficient.

The slope of the ducts with a diameter of moles has an inverse relation. It is 1 to 2 percent for the molar drainage. A slope of more than 7 percent will cause erosion and degradation. To smooth the slope before digging the duct of mole, it can be compared to the leveling of the earth. Long channels usually 
deteriorate sooner than short drains, so the appropriate length varies according to the type of soil and the slope of the earth. And it is usually $100-150$ meters. Once the ducts are constructed, the moisture content of the soil is appropriate during drilling, that is, not too dry or too wet. Excessive dryness causes the moles to malfunction. When constructing the duct, the molar drain begins to slip in the direction of the image, as it causes longer life [44].

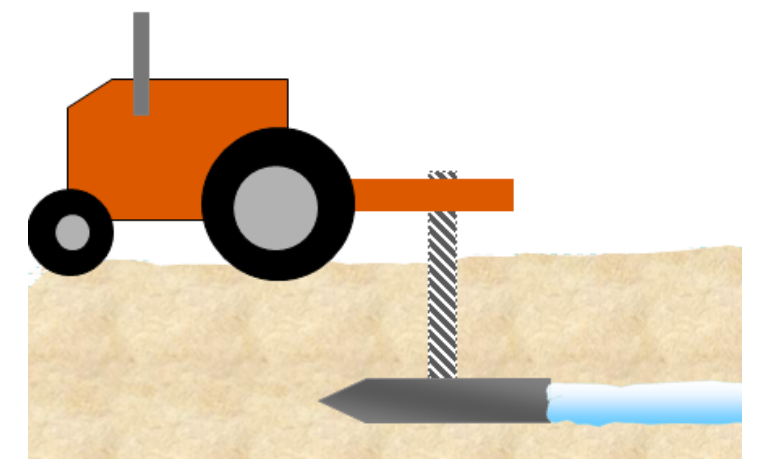

Figure 4. Establishment of drainage mole (Prepared by R Dehghani).

Drainage by pipe: In this drainage system, pipes, clay, cement, plastic and metal pipes are used depending on the conditions and facilities. After insertion of a suitable puncture tube placed in a sandy bed with large branches and rocks, so that it does not damage the tubes until the surface of the earth is filled with the material in place and the surface of the ground (Figure 5).

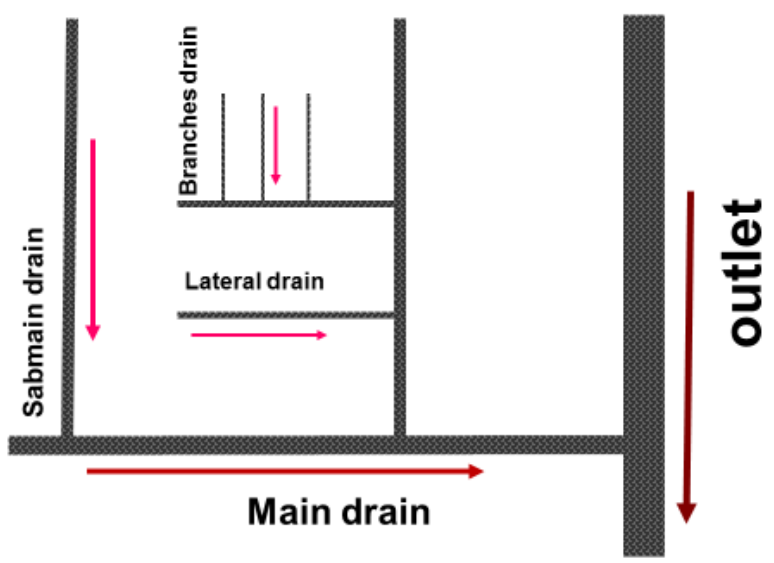

Figure 5. Pipe drainage system (Prepared by R Dehghani).

The benefits of this method include non-occupation of the earth's surface, access to the farm and, as a result, the timely implementation of the plant's essential matters at the planting stage and its harvesting is practicable, or other human activities are feasible for the construction of the required facilities, while the costs of maintaining the system with pipes is low, the used pipes include pottery, cement, plastic, metal hinges are used as the final piece in a seamless or plastic pipeline $[42,43]$.

\section{Types of underground drainage systems}

Gridiron system or parallel drainage: In this system, the drainages are aligned and the subsidiary drains are perpendicular to the main drains. This system is in relatively flat areas with regular shape and in soils with the same hydraulic conductivity coefficient (Figure 6).

\section{Gridiron system or parallel drainage}

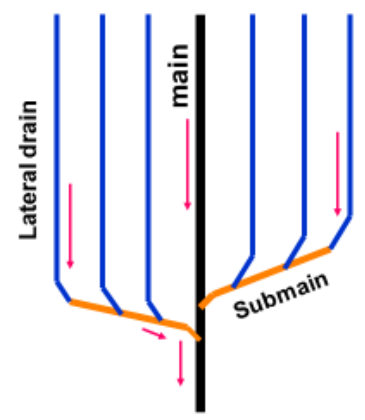

Figure 6. Gridiron system or parallel drainage (Prepared by $R$ Dehghani).

Herring-bone drainage system: In this drainage system, the subsidiary drains are aligned and connected to the main drain with a certain angle (Figure 7). This method is used in some cases where the main drainage is located in the bottom line and is in the direction of a maximum slope. Subsidiary drains connect to the main drainage with an appropriate angle.

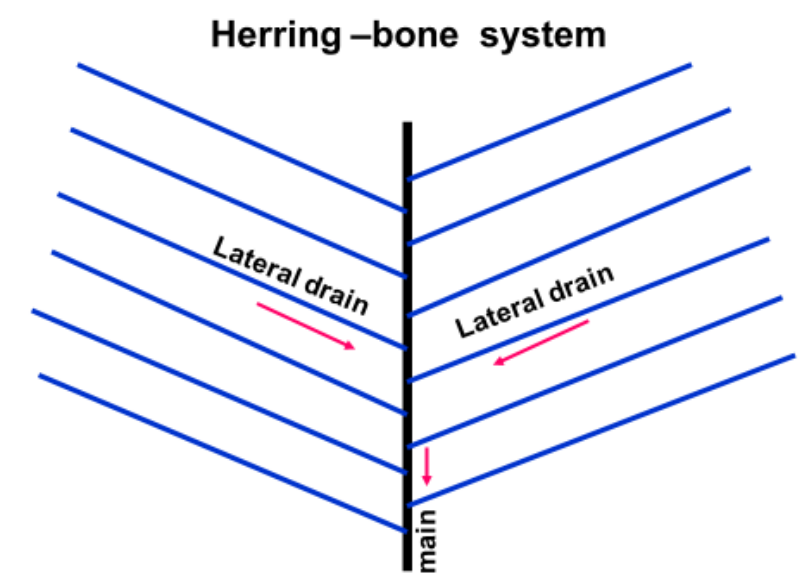

Figure 7. Herring-bone drainage system (Prepared by R Dehghani).

Composite or double system drainage: This system is created by integrating two parallel and creeping systems, and sometimes it is assumed that the earth has two bottom lines (Figure 8). 


\section{Composite system}

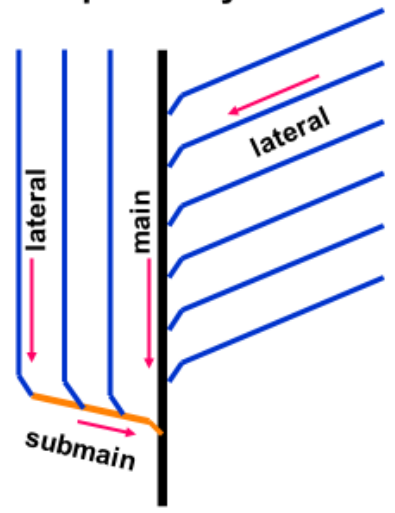

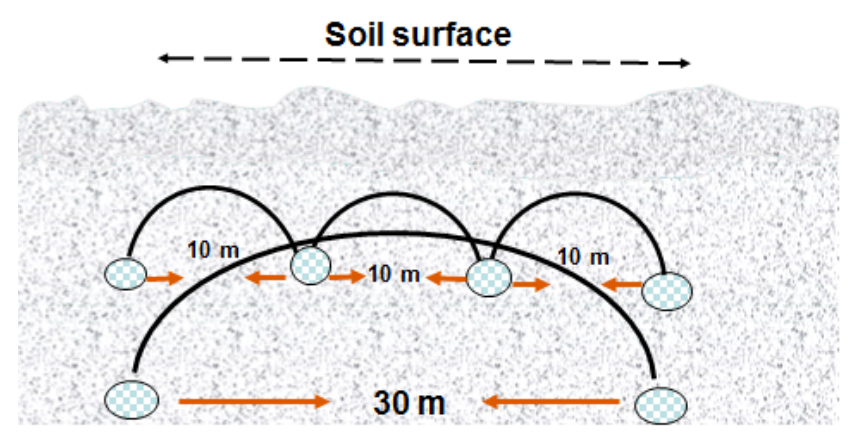

Figure 10. Relationship between drainage depth and distance (Prepared by R Dehghani)

\section{Calculation of the distances of the drain branches}

Figure 8. Composite or double system drainage (Prepared by $R$ Dehghani).

Natural contour drainage: This system is sometimes used to indicate that the topography of the land in different parts of the farm has distinct slopes. In this case, the main drainage is located on low-altitude land [43] (Figure 9).

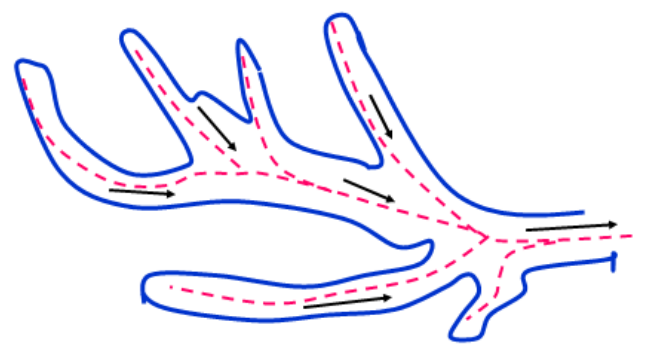

Figure 9. Natural contour drainage (Prepared by R Dehghani).

\section{Depth of drainage}

To determine the depth of the experimental method, the depth of drainage depends on the soil texture, the depth of the impervious layer and the use of drainage. The maximum depth is 2 metres. Underground drainage is being carried out in areas that, in addition to solving health problems and reducing transmitter populations, such as mosquitoes, are used for valuable grains that require land without water and no salt. The relationship between drainage depth and distance of drainages is one of the decisive factors, the depth of the drains is greater, the greater the distance between them, the cost of the project will be relatively low (Figure 10).

Depth of drainage is from 0.8 to 2 meters depending on soil condition, climate, type of plants and drainage application. The maximum slope for underground subsidiary drains with a diameter of $10 \mathrm{~cm}$ is 2 to 3 per thousand and for a diameter of $20 \mathrm{~cm}$ is 1 to 2 per thousand. The smaller the slope, the chosen diameter of pipe is smaller. The best angle for connecting subsidiary drains to the original is 60 degrees [45].
Drain intervals must be such that the groundwater level falls to the required level between the two drains. To determine the distances of the drain branches, a drain with a suitable depth (2 metres) is dug with respect to the surface of the station so that it can properly lower the surface, then at regular intervals of 5, $10,15,20,25$ and 30 meters, according to the physical and chemical structure of the soil, they dig the earth with a diameter of 1 meter and to a depth of 1 meter, then dump the pits and fill it with water and put covering on them in order to prevent evaporation of the water. After 2 to 5 hours, the amount of water in these pits decreases. If it is completely lowered at 5, 10, or 15 meters, it means that one drain branch can be up to 15 meters. Therefore, the distance between the drain branches is considered to be $30 \mathrm{~m}$, since two parallel drains, each up to $15 \mathrm{~m}$ and a total of $30 \mathrm{~m}$ drain the earth $[42,43]$ (Figure 11).

\section{Surface rainwater management}

Rainfall surface water management is one of the environmental health problems that occur in some cases in years and in different areas, while these fluid streams mixed with leakage of waste water also causes groundwater pollution, in addition to providing a suitable breeding ground for mosquitoes [12-15].

The most important aspect is the occurrence of seasonal rains in areas of flood occurrence which, if not controlled, would seriously damage the urban and rural facilities and cause human and animal deaths, limit the flow of flood in a given width of the river to assistance is provided to structures such as gutters and flood straps. Simultaneous with reducing the amount of rainfall, the flow rate of water reduces and provides suitable conditions for the development of transmitter mosquitoes.

Apart from this, water durability on the floor of this type of channels causes dispersion of unpleasant odors. To avoid this problem, it is possible to use a narrow duct on the floor of these canals to reduce water content in dry seasons the flow rate of the water is so large that it does not cause mosquitoes laying or bad odors. Due to the presence of a small section at the bottom of the canal of water, the velocity of the current 
water reaches the lowest, and does not result in the deposition of suspended matter or the breeding of transmitters [45].

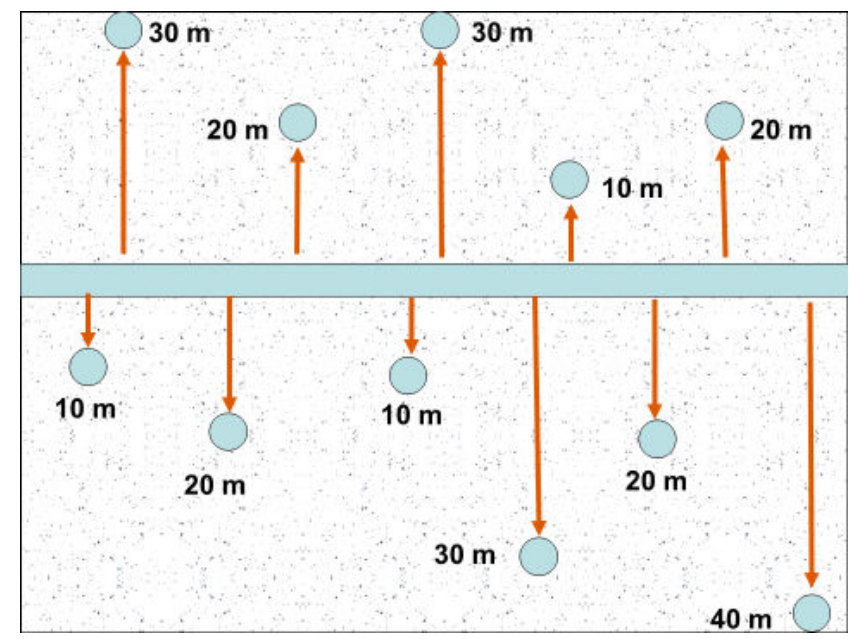

Figure 11. How to determine the distance between branches of drains (Prepared by R Dehghani).

\section{Eliminating breeding habitat of pests}

Toxic arthropods, including spiders and scorpions, occupy a wide range of habitats, including desert, coastal and mountainous areas in and around the occupied areas of the villages and cities, causing people to bite in rural and urban areas [46-49].

Scorpions varies in different regions, so there are various habitats $[50,51]$, the recognition of habitats of these creatures, which may include stone pillars, holes and wall gaps, building blocks, shells of trees at low altitudes, old and ruined walls, natural holes and gaps, mosaic gaps and joints, and concrete parts of the garden margin, stone rocks around agricultural lands, building waste, wood and timber, trunks of cut or unstuck trees can help to avoid scorpion and its possible bites [52-54].

To prevent the risk of abundance and damage of mice, especially in areas where food is provided in various forms, by properly collecting and burying waste, weeds, residues of crops, and eradicating these areas of weed or deep plowing can reduce the density of mice in the following seasons. The removal of the shelter and the removal of garbage and food supply are easily accessible to mice. Waste can be a natural bed for the production of a large number of insects, including sand flies and other arthropods [55,56].

Snakes are considered to be major hunters of mice, but if garbage causes mice to grow, the hunters of these animals, including snake and non-poisonous snakes, are attracted to their predators, the mouse [57]. Therefore, failure to observe the principles of proper collection of waste will lead to the bites of human beings by toxic animals like snakes. The collection and sanitation can prevent hunters from approaching mice and arthropods [58-62].

Studies have shown that hygienic pest management has always been considered by using various methods, especially environmental methods such as eliminating their breeding habitat [37]. Drainage is one of the most important environmental control methods and it is necessary to maintain the water cycle or hydrological cycle in one place. In many cases, the cost of storing the drainage system is lower than the annual cost of insecticide supply [42].

In Iran, most of all, easy and immediate methods, i.e., the use of pesticides are considered. This method is immediate and temporary and the damage is very high $[44,45]$. But in the arid and central regions of Iran, the stagnant waters are more likely to be related to household sewage wells that are not properly protected and play a role as a breeding habitat for a number of transmitters, including mosquitoes.

In these areas, chalcedony mosquitoes run their abundance in these domestic sewage wells, and these wells are good breeding place mosquitoes of Culex genus. The use of other methods, such as the installation of insect caps, is recommended to prevent the entry and exit of mosquitoes to wells. The installation of ventilation tubes is essential for the release of odor gases, these ventilation tubes must be covered with stainless steel netting. These nettings prevent the entry of mosquitoes and lay in the wells of the sewage $[14,43]$.

Garbage collection and its landfill can prevent hunters from approaching mice and arthropods. Scorpions are inaccessible to residential areas, because wastewater, especially containing food residues, attracts insects and arthropods that are used as food and these creatures can attract hunters, including scorpions, and increase the risk of stings among people, so removing the landfill and preventing its dispersal can help to reduce the attraction and abundance of scorpions [56].

\section{Conclusion}

Environmental control methods with health pests compared with using chemical pesticides, which are the most polluting substances in nature, is a safe, durable and natural way that can be used to combat it. Obviously, water conditions, air, environmental and pest species are effective in choosing the type of method. Therefore, the development of a coherent and comprehensive plan for the prevention and control of health pest habitats can be successful permanently monitored by health workers. These methods are superior in comparison with other methods of combat due to lack of environment pollution, and the resulting risks are less. Such actions are subject to strong management in the direction of specialized groups in the fields needed and in all the research and educational centers and organizations of the university that conducts studies and implementation of fundamental and applied research projects, especially in the regions Problem can lead to a decrease in the number of hits.

\section{Acknowledgment}

This study was carried out at the Social Determinants of Health (SDH) Research Center, on the Health of the School of Public Health of Kashan University of Medical Sciences. In this way we appreciate the members of the faculty of the Center and the 
Department of Environmental Health and School of Health, Ahvaz Jundishapur University of Medical Sciences, Ahvaz, Iran.

\section{References}

1. Dehghani R. Solpugidophobia in Iran: real or illusion. Lexis Publishing Corporation 2017.

2. Dehghani R, Arani MG. Scorpion sting prevention and treatment in ancient Iran. J Trad Compl Med 2015; 5: 75-80.

3. Dehghani R, Hoseindoost G, Bidgoli NS, Zamani M, Ghadami F. Study on pests of residential complex and student dormitories of Kashan University of Medical Sciences, Iran. J Entomol Res 2017; 41: 311-316.

4. Dehghani R, Moabed S, Kamyabi F, Haghdoost A, Mashayekhi M, Soltani S. Scorpions Fauna of Kerman Province-Iran. J Kerman University Med Sci 2008; 2: 172-181.

5. Dehghani R, Vazirianzadeh B, Hejazi SH, Jalayer N. Frequency of Sarcoptes scabiei infestation in patients referred to the parasitology laboratory in Isfahan, Iran (1996-2002). Jundishapur J Microbiol 2009; 2: 65-70.

6. Dehghani R, Limoee M, Ahaki A. Research note first report of family infestation with pubic louse (Pthirus pubis; Insecta: Anoplura: Pthiridae) in Iran-a case report. Trop Biomed 2013; 30: 152-154.

7. Dehghani R, Hashemi A, Takhtfiroozeh S, Chimehi E. Bed bug (Cimex lectularis) outbreak: A cross-sectional study in Polour, Iran. Iran J Dermatol 2016; 19: 16-20.

8. Rasti S, Dehghani R, Khaledi HN, Takhtfiroozeh SM, Chimehi E. Uncommon human urinary tract myiasis due to Psychoda sp. Larvae, Kashan, Iran: a case report. Iran J Parasitol 2016; 11: 417-721.

9. Dehghani R, Zarghi I, Sayyedi H, Genital myiasis of a sheep by Wohlfahrtia magnifica, in Ghamsar, Kashan, Iran. Bangl J Med Sci 2014; 13: 306-310.

10. Talar S, Dehghani R, Yeganeh MA. Chrysomya bezziana infestation. Arch Iran Med 2002; 5: 56-58.

11. Dehghani R, Sedaghat MM, Bidgoli MS. Wound myiasis due to Musca domestica (Diptera: Muscidae) in Persian horned viper, Pseudocerastes persicus (Squamata: Viperidae). J Arthropod Borne Dis 2012; 6: 86-89.

12. Dehghani R, Miranzadeh MB, Yosefzadeh M, Zamani S. Fauna aquatic insects in sewage maturation ponds of Kashan University of Medical Science 2005. Pak J Biol Sci 2007; 10: 928-931.

13. Dehghani R, Zarghi I, Aboutalebi M, Barzegari Z, Ghanbari M. Fauna and habitat of aquatic arthropods of Kashan in 2010. Bangl J Med Sci 2014; 13: 306-310.

14. Dehghani R, Akbari H, Vazirianzadeh B. A prospective study on the seasonal frequencies of insect bites (Diptera: Culicidae and Phlebotominae) and the related environmental and protective method factors in the city of Kashan, central of Iran, 2009. Pak J Med Sci 2012; 28: 158-161.
15. Dehghani R, Takhtfiroozeh M, Kanani F, Aslani S. Case report of Stomoxys calcitrans bites in residential area of Kashan, Iran. J Mazandaran Univ Med Sci 2014; 23: 257-261.

16. Vazirianzadeh B, Mehdinejad M, Dehghani R. Identification of bacteria which possible transmitted by Polyphaga aegyptica (Blattodea: Blattidae) in the region of Ahvaz, SW Iran, 2009. Jundishapur J Microbiol 2009; 2: 36-40.

17. Vazirianzadeh, Dehghani R, Mehdinejad M, Sharififard $\mathrm{M}$, Nasirabadi N. The first report of drug resistant bacteria isolated from the brown-banded cockroach, Supella longipalpa, in ahvaz, South-Western Iran. J Arthropod Borne Dis 2014; 8: 53-59.

18. Dehghani R, Vazirianzadeh B, Asadi MA, Akbari H, Moravvej SA. Infestation of rodents (Rodentia: Muridae) among houses in Kashan, Central Iran. Pak J Zool 2012; 44: 1721-1726.

19. Dehghani R, Talaee R, Sehat M, Ghamsari NN, Mesgari L. Surveying the rate of using cosmetics among the Kashans women. J Biol Todays World 2017; 6: 27-32.

20. Fathabadi N, Mohammadi M, Dehghani R, Kardan M, Atoof F, Farahani M, Moradi M. The effects of environmental parameters on the radon exhalation rate from the ground surface in HBRA in Ramsar with a regression model. Life Sci J 2013; 10: 563-569.

21. Dehghani R, Limoee M, Zarghi I. The review of pesticide hazards with emphasis on insecticide resistance in arthropods of health risk importance. Scientific J Kurdistan Univ Med Sci 2012; 17: 82-98.

22. Zarrintab M, Mirzaei R, Mostafaei G, Dehghani R, Akbari H. Concentrations of Metals in Feathers of Magpie (Pica pica) from Aran-O-Bidgol City in Central Iran. Bull Environ Contam Toxicol 2016; 96: 465-471.

23. Mostafaii G, Dehghani R, Najafi M, Moosavi G, Rajaei M, Moghadam VK, Takhtfiroozeh S. Frequency of urban pests and pesticides consumption in the residential houses of the east of Tehran city, Iran. J Entomol Res 2017; 41: 125-132.

24. Dehghan R, Moosavi G, Takhtfiroozeh SM, Rashedi G. Investigation of the removal of cyanide from aqueous solutions using biomass Saccharomyces cerevisiae. Desalin Water Treat 2016; 57: 27349-27354.

25. Dehghani R, Yunesian M, Sahraian MA, Gilasi HR, Moghaddam VK. The evaluation of multiple sclerosis dispersal in Iran and its association with urbanization, life style and industry. Iran J Publ Health 2015; 44: 830-838.

26. Dehghani R, Sahraian MA, Yunesian M, Hadeii M, Gilasi HR, Kazemi-Moghaddam V. Reply to urbanization theory for growing trend of multiple sclerosis letter. Iranian J Publ Health 2017; 46: 1601-1602.

27. Dehghni R, Vazirianzadeh B, Rahimi Nasrabadi M, Moravvej SA. Study of scorpionism in Kashan in central of Iran. Pak J Med Sci 2010; 26: 955-958.

28. Dehghani R, Khamehchian $\mathrm{T}$, Vazirianzadeh $\mathrm{B}$, Vatandoost H, Moravvej S. Toxic effects of scorpion, 
Hemiscorpius lepturus (Hemiscorpiidae) venom on mice. J Anim Plant Sci 2012; 22: 593-596.

29. Ghafourian M, Ganjalikhanhakemi N, Hemmati AA, Dehghani R, Kooti W. The effect of Hemiscorpius lepturus (Scorpionida: Hemiscorpiidae) venom on leukocytes and the leukocyte subgroups in peripheral blood of rat. J Arthropod Borne Dis 2016; 10: 159-167.

30. Dehghani R, Khamehchian T, Miranzadeh MB. Surveying on the biologic behaviors of Hemiscorpius lepturus Peters 1861, scorpion in laboratory (Khuzestan, Iran) (Scorpions: Hemiscorpiidae). Pak J Biol Sci 2007; 10: 3097-3102.

31. Ahmadimarzale M, Sabuhi H, Bidgoli MS, Dehghani R, Hoseindoost G, Mesgari L. Study of scorpion species abundance in cities Aran \& Bidgol and Kashan, Isfahan, Iran. J Entomol Res 2017; 41: 337-342.

32. Motevalli Haghi F, Dehghani R. A review of scorpions reported in Iran. Journal of Mazandaran Univ Med Sci 2017; 27: 213-226.

33. Yousef Mogaddam M, Dehghani R, Enayati AA, FazeliDinan M, Motevalli Haghi F. Epidemiology of scorpionism in Darmian, Iran, 2015. J Mazandaran Univ Med Sci 2016; 26: 131-136.

34. Dehghani R, Rafinejad J, Fathi B, Shahi MP, Jazayeri M, Hashemi A. A retrospective study on scropionism in Iran (2002-2011). J Arthropod Borne Dis 2017; 11: 194-203.

35. Shahbazzadeh D, Amirkhani A, Djadid ND, Bigdeli S, Akbari A, Ahari H, Amini H, Dehghani R. Epidemiological and clinical survey of scorpionism in Khuzestan province, Iran (2003). Toxicon 2009; 53: 454-459.

36. Dehghani R, Kassiri H. Geographical distribution of scorpion Odontobuthus doriae in Isfahan Province, Central Iran. J Arthropod Borne Dis 2017; 11: 427-432.

37. Walker K. A review of control methods for African malaria vectors. Env Health Project 2002; 2: 618-627.

38. Stevens P. Environmental management activities in malaria control in Africa. Bull WHO 1984; 62: 77.

39. World Health Organization. Manual on Environmental Management for Mosquito Control, with special emphasis on malaria vectors. 1982; 66: 1-283.

40. Burian S. Developments in water supply and wastewater management in the United States during the 19th century. Water Resources Impact 2001; 3: 8-14.

41. Burian SJ, Nix SJ, Rocky-Durrans S, Pitt RE, Fan CY, Field R. Historical development of wet-weather flow management. J Water Res Plan Manag 1999; 125: 3-13.

42. Dehghani R, Mostafaei GR, Zarghi I. Drainage methods for the control of mosquitoes. Feyz J Kashan Univ Med Sci 2011; 15: 161-173.

43. Bruce-Chwatt LJ. Essential malariology. William Heinemann Medical Books Ltd. (2nd Edn.). London $1985 ; 345$.

44. Bennett DL, George R, Russell B. Mole drainage for increased productivity in the south west irrigation area. Department of Agriculture and Food, Western Australia, Perth. Bulletin 2005; 4610.
45. Rozendaal JA, WHO Vector control: methods for use by individuals and communities. Vector control: methods for use by individuals and communities/prepared by Jan A. Rozendaal 1997.

46. Dehghani R, Talaee R, Rafeenejad J, Seydi- Rezvani R, Karimi F. Brown widow spider bite (Loxosceles sp., Araneae, Sicariidae): a case report from Kashan, Iran. Iran J Dermatol 2017; 20: 32-35.

47. Kassiri H, Kasiri A, Kasiri E, Abdian P, Matori F, Lotfi M. Epidemiological characteristics and incidence rate of definite scorpion stings in Mahshahr County, Iran: multivariate analysis of 1635 cases. Asian Pacific J Trop Dis 2015; 5: 80-84.

48. Dehghani R, Kamiabi F, Mohammadi M. Scorpionism by Hemiscorpius spp. in Iran: a review. J Venom Animals Toxins Trop Dis 2018; 24: 8.

49. Dehghani R, Djadid ND, Shahbazzadeh D, Bigdelli S. Introducing Compsobuthus matthiesseni (Birula, 1905) scorpion as one of the major stinging scorpions in Khuzestan, Iran. Toxicon 2009; 54: 272-275.

50. Dehghani R, Kamiabi F. Frequency of Odonthubutus doriae Thorell 1876 nests in desert soils, esfahan, Iran. J Entomol Res 2017; 41: 13-18.

51. Dehghani R, Kamiabi F, Mohammadzadeh N. Burrowing habits of two Arthropods; Odenthobutus doriae and Hemilepistus schirasi in desert of Isfahan, Iran. J Entomol Res 2017; 41: 113-118.

52. Dehghani R, Valizade R, Mahmoodi S. A review of the scorpion predators and the introduction of Scarites subterraneus, as a new predatory of them in Iran. J Entomol Res 2016; 40: 291-296.

53. Sanaei-Zadeh H, Marashi SM, Dehghani R. Epidemiological and clinical characteristics of scorpionism in Shiraz (2012-2016); development of a clinical severity grading for Iranian scorpion envenomation. Med J Islam Republ Iran 2017; 31: 158-166.

54. Gefen E, Ar A. Temperature dependence of water loss rates in scorpions and its effect on the distribution of Buthotus judaicus (Buthidae) in Israel. Comparative Biochem Physiol Mol Integr Physiol 2006; 144: 58-62.

55. Miranzadeh MB, Gillasi H, Rabbani D, Dehghani R, Hoseindoost G, Takhtfiroozeh S, Kharizadeh A. The incidence trend of cutaneous leishmaniasis in Aran-Bidgol city in Iran (2002-2015). J Entomol Res 2017; 41: 329-336.

56. Dehghani R, Shahrisvand B, Mostafaeii G, Atharizadeh M, Gilasi H, Mofrad MR, Hosseindoost G, Takhtfiroozeh S. Frequency of arthropoda in urban wastes compost process at laboratory condition. J Entomol Res 2016; 40: 357-364.

57. Kazemi-Moghaddam V, Dehghani R, Hadei M, Dehqan S, Sedaghat MM, Latifi M, Salavi-Moghaddam S. Rodentborne and rodent-related diseases in Iran. Compar Clin Pathol 2018; 13: 1-13. 
Environmental management methods to control the vector of communicable diseases with emphasis on drainage: A review article

58. Dehghani R, Sharif A, Madani M, Kashani HH, Sharif MR. Factors influencing animal bites in Iran: a descriptive study. Osong Publ Health Res Persp 2016; 7 : 273-277.

59. Dehghani R, Dadpour B, Keyler D, Panjehshahi M, Jazayeri M, Mehrpour O, Tamijani AH. A survey on nonvenomous snakes in Kashan (Central Iran). J Biol Todays World 2016; 5: 65-75.

60. Dehghani R, Mehrpour O, Shahi MP, Jazayeri M, Karrari P, Keyler D, Zamani N. Epidemiology of venomous and semi-venomous snakebites (Ophidia: Viperidae, Colubridae) in the Kashan city of the Isfahan province in Central Iran. J Res Med Sci 2014; 19: 33-40.

61. Dehghani R, Sharif A, Assadi MA, Kashani HH, Sharif MR. Fungal flora in the mouth of venomous and nonvenomous snakes. Compar Clin Pathol 2016; 25: 1207-1211.
62. Dehghani R, Sharif MR, Moniri R, Sharif A, Kashani HH. The identification of bacterial flora in oral cavity of snakes. Compar Clin Pathol 2016; 25: 279-283.

\section{*Correspondence to}

Kassiri H

Department of Medical Entomology

School of Health

Ahvaz Jundishapur University of Medical Sciences

Iran 